\title{
Ribosomal protein S6 phosphorylation is a determinant of cell size and glucose homeostasis
}

\author{
Igor Ruvinsky, ${ }^{1}$ Nitzan Sharon, ${ }^{1}$ Tal Lerer, ${ }^{1}$ Hannah Cohen, ${ }^{1}$ Miri Stolovich-Rain, ${ }^{1}$ Tomer Nir, ${ }^{2}$ \\ Yuval Dor, ${ }^{2}$ Philip Zisman, ${ }^{3}$ and Oded Meyuhas ${ }^{1}$ \\ ${ }^{1}$ Department of Biochemistry, ${ }^{2}$ Department of Cellular Biochemistry, and ${ }^{3}$ The Lautenberg Center for General and Tumor \\ Immunology, The Hebrew University-Hadassah Medical School, Jerusalem 91120, Israel
}

\begin{abstract}
The regulated phosphorylation of ribosomal protein (rp) S6 has attracted much attention since its discovery in 1974, yet its physiological role has remained obscure. To directly address this issue, we have established viable and fertile knock-in mice, whose rpS6 contains alanine substitutions at all five phosphorylatable serine residues $\left(\mathrm{rpS}^{\mathrm{P}^{\mathrm{P}-}-}\right)$. Here we show that contrary to the widely accepted model, this mutation does not affect the translational control of TOP mRNAs. rpS6 $^{\mathbf{P}-/-}$ mouse embryo fibroblasts (MEFs) display an increased rate of protein synthesis and accelerated cell division, and they are significantly smaller than $\mathbf{r p S 6}^{\mathrm{P}+/+}$ MEFs. This small size reflects a growth defect, rather than a by-product of their faster cell division. Moreover, the size of rpS6 $^{\mathrm{P}-1-}$ MEFs, unlike wild-type MEFs, is not further decreased upon rapamycin treatment, implying that the rpS6 is a critical downstream effector of mTOR in regulation of cell size. The small cell phenotype is not confined to embryonal cells, as it also selectively characterizes pancreatic $\beta$-cells in adult $\mathbf{r p S 6}^{\mathbf{P}-/-}$ mice. These mice suffer from diminished levels of pancreatic insulin, hypoinsulinemia, and impaired glucose tolerance.
\end{abstract}

[Keywords: Knock-in mouse; TOP mRNAs; translational control; cell size; glucose intolerance; hypoinsulinemia]

Received May 15, 2005; revised version accepted July 20, 2005.

Phosphorylation of rpS6 was first discovered during liver regeneration (Gressner and Wool 1974), and later on in response to numerous agents and alterations in the cellular milieu (for review, see Chan and Wool 1988). The phosphorylation sites in rpS6 have been mapped to five clustered residues-Ser235, Ser236, Ser240, Ser244, and Ser247-which are located at the C terminus (Krieg et al. 1988) and are conserved from Drosophila to mammals (Fumagalli and Thomas 2000). This phosphorylation has attracted much attention due to its temporal correlation with the initiation of protein synthesis, and the suggestion that ribosomes with the highest proportion of phosphorylated rpS6 have a selective advantage in mobilization into polysomes (for review, see Fumagalli and Thomas 2000). Phosphorylation of rpS6 is carried out in Drosophila by a single kinase, dS6K, whereas in mice the phosphorylation is performed by two closely related kinases, S6K1 and S6K2 (Fumagalli and Thomas 2000). Analysis of S6 phosphorylation in mouse cells deficient of either of these kinases suggests that both are required

${ }^{4}$ Corresponding author.

E-MAIL meyuhas@cc.huji.ac.il; FAX 972-2-6757379.

Article and publication are at http://www.genesdev.org/cgi/doi/10.1101/ gad.351605. for full S6 phosphorylation, with predominance of S6K2. However, phosphorylation of rpS6 can still be detected at Ser235 and Ser236 in cells lacking both these kinases $\left(\mathrm{S} 6 \mathrm{~K}^{-1-} / \mathrm{S} 6 \mathrm{~K} 2^{-/-}\right)$, conceivably by mitogen-activated protein kinase (Pende et al. 2004).

S6Ks have been implicated as important positive regulators of cell and body size. Thus, most dS6K-null Drosophila exhibit embryonic lethality, with the few surviving adults having a severely reduced body size, due to a decrease in cell size rather than a decrease in cell number (Montagne et al. 1999). S6K $1^{-/-}$mice are significantly smaller at birth (Shima et al. 1998), with a reduced size of adult pancreatic $\beta$-cells, diminished levels of circulating insulin, and a mild glucose intolerance (Pende et al. 2000). S6K2 $2^{-/-}$mice are not smaller than the wild-type mice, whereas embryonic and post-natal growth of $\mathrm{S} 6 \mathrm{~K}^{-1-} / \mathrm{S} 6 \mathrm{~K}^{-1-}$ of surviving mice is similar to that of S6K1 $1^{-1-}$ mice (Pende et al. 2004). Nevertheless, despite the increasing list of physiological roles assigned to S6K activity, the involvement of its best-characterized substrate, rpS6, as well as its other assigned substrates (de Groot et al. 1994; Wilson et al. 2000; Harada et al. 2001; Wang et al. 2001; Harrington et al. 2004; Raught et al. 2004; Richardson et al. 2004), in any of these functions has remained unknown. 
A prevailing model has implicated rpS6 phosphorylation in translational control of TOP mRNAs. These mRNAs are characterized by an oligopyrimidine tract at their $5^{\prime}$ terminus $\left(5^{\prime}\right.$-TOP) and encode various proteins associated with the function or the assembly of the translational apparatus (Meyuhas 2000). The translation of these mRNAs is selectively activated when resting cells are induced to grow (increase in their mass) or to proliferate, or when amino acid-starved cells are refed (Tang et al. 2001; Stolovich et al. 2002). The 5'-TOP motif comprises a critical translational cis-regulatory element in these mRNAs (Levy et al. 1991).

The temporal relationship between the translational activation of TOP mRNAs and the activation of S6K and the phosphorylation of its substrate, rpS6, led to a model that related translational efficiency of TOP mRNAs to rpS6 phosphorylation (Fumagalli and Thomas 2000). However, recent reports have shown that TOP mRNAs are subject to normal translational control in $\mathrm{S} 6 \mathrm{~K}^{-/-}$ embryonic stem (ES) cells, whose rpS6 is constitutively unphosphorylated (Tang et al. 2001; Stolovich et al. 2002). Consequently, the physiological role of rpS6 phosphorylation has once again become obscure. We set out, therefore, to elucidate the role rpS6 phosphorylation by serine-to-alanine substitution of all five phosphorylatable residues in mouse rpS6. To this end, we have knocked in a mutated $r p S 6$ gene by homologous recombination and have characterized the phenotype of the resulting homozygous mice.

\section{Results}

Generation of $\mathrm{rpS}^{P-/-}$ knock-in mice

Replacement of serine residues 235, 236, 240, 244, and 247 with alanines was carried out by site-directed mutagenesis, which also created AatII and EcoRV sites 5' and 3 ', respectively, to the mutated serine codons. A targeting vector containing these alterations was electroporated into ES cells, and three out of five clones with homologous recombination at the rpS6 locus were selected for establishing chimeric mice, which transmitted the mutant allele. The F2 generation was genotyped by Southern blot and PCR analyses (Fig. 1B,C). The frequency of $\mathrm{rpS}^{\mathrm{P}+/+}, \mathrm{rpS}^{\mathrm{P}+/-}, \mathrm{rpS}^{\mathrm{P}-/-}$ was 1:2:1 (data not shown). RT-PCR analysis of total liver RNA from
Figure 1. Generation of unphosphorylatable $r p S 6$ allele $\left(\mathrm{rpS}^{\mathrm{P}-/-}\right)$. (A) The structures of the endogenous rpS6 gene, targeting vector, and the mutated locus. The position of the phosphorylatable serine residues and the respective alanine substitutes in exon 5 is indicated by Ss or As, respectively. (Triangles) loxP sites; (neo) neomycin-resistance gene; $(D T A)$ diphtheria toxin-A chain gene. (B) Southern blot of ApaLI- or Asp700-digested genomic DNA from wild-type, heterozygous, and homozygous mice hybridized to the probes are indicated at the bottom. The wild-type allele $(5.7$ or $5.4 \mathrm{~kb}$, respectively) and targeted allele (7.8 and 4.4, respectively) are indicated. $(C)$ PCR products of genomic DNA using primers that flank the mutated sites as specified in Materials and Methods. The products were digested with EcoRV and separated by agarose gel electrophoresis. The wild-type allele (639 bp) and the doublet of the targeted allele (339 and $305 \mathrm{bp}$ ) are indicated. $(D)$ Total RNA from $\mathrm{rpS}^{\mathrm{P}+/-}$ ES cells was extracted and subjected to RT-PCR, as described in Materials and Methods. Equal aliquots of the resulting DNA were either untreated $(-)$ or digested by AatII $(+)$ and separated by agarose gel electrophoresis. The wild-type allele (171 bp) and the doublet of the targeted allele ( 84 and $87 \mathrm{bp}$ ) are indicated. Total RNA (two samples for each genotype) and cytoplasmic proteins from $\mathrm{rpS}^{\mathrm{P}+/+}(+/+)$ and rpPS6 $^{\mathrm{P}-/-}(-/-)$ MEFs were subjected to Northern and Western blot analyses, using the indicated cDNA probes or antibodies, respectively. (E) Cytoplasmic extracts from $\mathrm{rpS}^{\mathrm{P}+/+}$ and $\mathrm{rpPS}^{\mathrm{P}-/-}$ mice were subjected to Western blot analysis using the indicated antibodies. (C) Control liver; (R) regenerating liver. $(F)$ Primary MEFs were serum-starved for $48 \mathrm{~h}$ and then serum-refed in phosphate-free medium for $2.5 \mathrm{~h}$, and labeled with $\left[{ }^{32} \mathrm{P}\right]$ orthophosphate during the last $2 \mathrm{~h}$. Phosphorylated polysomal proteins were analyzed as described in Materials and Methods. The positions of molecular size markers are shown at the left of the autoradiography. rpS6 migrates at $32 \mathrm{kDa}$.

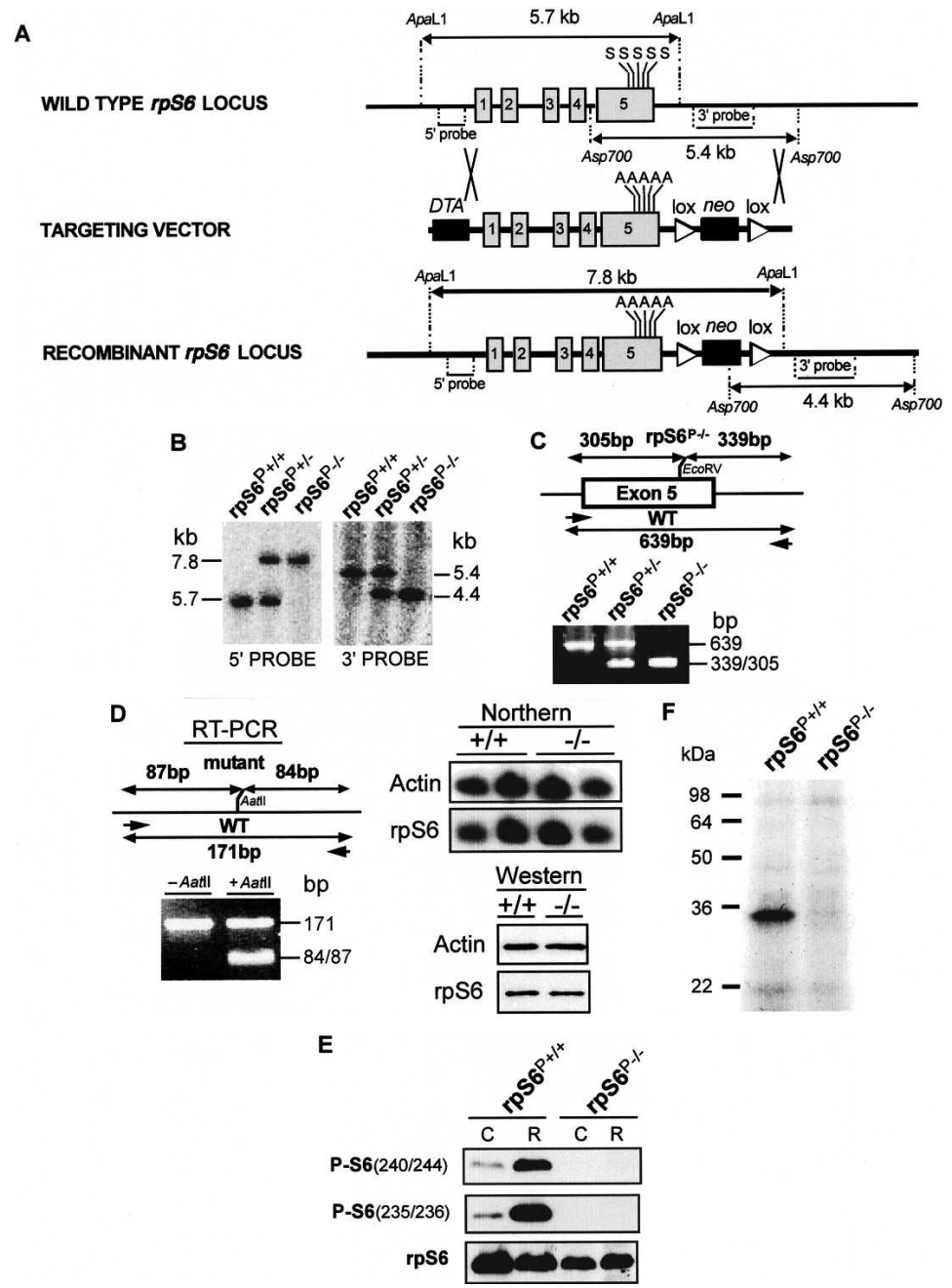


$\mathrm{rpS}^{\mathrm{P}+/+}$ and $\mathrm{rpS6}^{\mathrm{P}-/-}$ mice demonstrated expression of just the $r p S 6^{\mathrm{P}-/-}$ allele (data not shown). The mutant rpS6 allele was expressed at least as well as the wild-type allele in heterozygous ES cells, as exemplified by RTPCR analysis of the respective two transcripts (RT-PCR in Fig. 1D). Moreover, the presence of the neo gene immediately downstream of the rpS6 gene, as well as the substitution of nucleotides and amino acids, did not impede the abundance of the corresponding mRNA and protein, respectively, in differentiated homozygous mouse embryo fibroblasts (MEFs) (see Northern and Western in Fig. 1D). Western blot analysis, using antiphospho-Ser235/236 or antiphospho-Ser240/244 antibodies, failed to detect any phosphorylation of these sites in rpS6 in livers of untreated or partially hepatectomized rpS6 $6^{\mathrm{P}-/-}$ mice. In contrast, phosphorylation of the respective sites in rpS6 from $\mathrm{rpS}^{\mathrm{P}+/+}$ mice was readily detected before the operation, and was considerably enhanced in the regenerating liver (Fig. 1E). Moreover, metabolic labeling of rpS6 with $\left[{ }^{32} \mathrm{P}\right]$ orthophosphate demonstrated that $\mathrm{rpS} 6$ is not phosphorylated on other sites in $\mathrm{rpS}^{\mathrm{P}-/-}$ MEFs (Fig. 1F). Taken together, these data clearly demonstrate that all phosphorylatable serine residues in rpS6 are absent in $\mathrm{rpS}^{\mathrm{P}-/-}$ mice. Interestingly, $\mathrm{rpS}^{\mathrm{P}-/-}$ mice appeared normal from their birth until adulthood and were largely indistinguishable from their wild-type or heterozygous littermates in weight, appearance, development, and fertility.

\section{rpS6 phosphorylation is dispensable for translational control of TOP mRNAs}

Early correlative studies led to the assumption that rpS6 phosphorylation is involved in translational control of a subset of mRNAs, TOP mRNA, rather than in global protein synthesis (Jefferies et al. 1994). However, later experiments conducted with cultured cells have clearly shown that translational activation of TOP mRNAs does not require rpS6 phosphorylation (Tang et al. 2001; Stolovich et al. 2002). Nonetheless, it has recently been shown that rpS6 is still phosphorylated at Ser235 and/or Ser236 in hepatocytes from S6K $1^{-/-} / \mathrm{S} 6 \mathrm{~K} 2^{-/-}$mice, by mitogen-activated protein kinase, and that the translation of their TOP mRNAs is normally regulated (Pende et al. 2004). To examine whether this residual phosphorylation of rpS6 is essential and/or sufficient for translational control of TOP mRNAs, we examined the translational behavior of these mRNAs in $\mathrm{rpS}^{\mathrm{P}-/-}$ mice and MEFs. Figure 2A shows that a typical TOP mRNA encoding rpL32 was translationally repressed in livers of both $\mathrm{rpS}^{\mathrm{P}+/+}$ and $\mathrm{rpS6}^{\mathrm{P}-/-}$ mice, as judged by its low association with polysomes. Partial hepatectomy, however, induced similar translational activation /recruitment into polysomes) of rpL32 mRNA in the regenerating liver of both genotypes of mice, even though rpS6 is phosphorylated only in the wild-type liver (Fig. 1F). A non-TOP mRNA, encoding superoxide dismutase (SOD), is translationally active before and after the operation (mostly associated with polysomes) in both $\mathrm{rpS6}^{\mathrm{P}+/+}$ and rpS6 ${ }^{\mathrm{P}-1-}$ mice (Fig. 2A). The translation of rpL32 mRNA

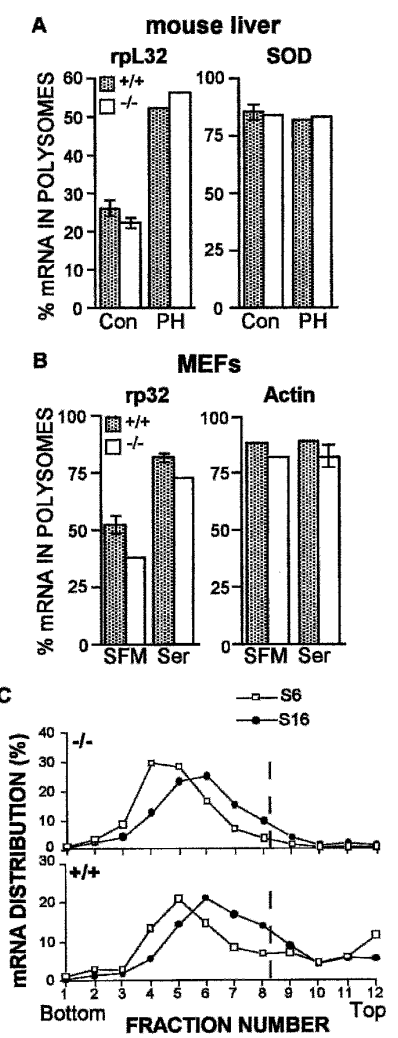

Figure 2. Translational activation of TOP mRNAs does not require rpS6 phosphorylation. $(A, B)$ Cytoplasmic extracts from untreated livers $(\mathrm{CON})$ or $23 \mathrm{~h}$ after partial hepatectomy $(\mathrm{PH})$, as well as from $72 \mathrm{~h}$ serum-starved (SFM) or $3 \mathrm{~h}$ serum-refed (Ser) MEFs were centrifuged through sucrose gradients and separated into polysomal and subpolysomal fractions. RNA from equivalent aliquots of these fractions was analyzed by Northern blot hybridization with cDNAs for SOD and rpL32 (liver) or actin and rpL32 (MEFs). The radioactive signals were quantified by PhosphorImager, and the relative translational efficiency is depicted as the average percentage of an mRNA engaged in polysomes. The data are presented as a mean $(n=2)$ or as a mean $\pm \operatorname{SEM}(n=3) .(C) \mathrm{rpS6}^{\mathrm{P}+/+}(+/+)$ and $\mathrm{rpS}^{\mathrm{P}-/-}(-/-) \mathrm{MEFs}$ were serum-starved for $72 \mathrm{~h}$ and then refed for $3 \mathrm{~h}$. Cytoplasmic extracts from these cells were centrifuged through sucrose gradients and separated into 12 fractions. RNA isolated from these fractions was applied to Northern blot analysis and hybridized with cDNAs for rpS6 and rpS16. The radioactive signals were quantified by PhosphorImager, and the result for each fraction is presented as the percentage of total mRNA (the vertical dashed line separates the polysomal fractions [left] and the subpolysomal fractions $[$ right]).

was more repressed in serum-starved $\mathrm{rpS}^{\mathrm{P}-/-}$ MEFs than in $\mathrm{rpS}^{\mathrm{P}+/+}$ MEFs, yet it underwent a more pronounced translational activation upon serum refeeding in the mutant relative to the wild-type cells (1.9-fold vs. 1.6-fold, respectively) (Fig. 2B). It can be argued that the lack of an inhibitory effect of the mutation on the translational activation of rpL32 mRNA might reflect an exceptional behavior of this mRNA, and/or poor resolution of its polysomal association, due to partitioning of the gradient into just two fractions. Hence, we set out to monitor the polysomal distribution of two other TOP mRNAs, 
encoding rpS6 and rpS16, in gradients divided into 12 fractions (Fig. 2C). The results demonstrate that not only was the translational efficiency of these mRNAs not impaired in $\mathrm{rpS6}^{\mathrm{P}-/-}$ cells, it was slightly augmented, as can be judged by the shift of the peaks toward heavier fractions (bottom-wise). Notably, the difference in the location of the peak fractions between rp S6 and rpS16 mRNAs reflects the size difference of their coding sequence (145 and 249 codons, respectively). Taken together, these results clearly disprove any causal relationship between rpS6 phosphorylation and translational activation of TOP mRNAs.

\section{rpS6 phosphorylation and global protein synthesis}

A previous study has demonstrated that rpS6 is located near the mRNA/tRNA-binding site, at the interface between the small and the large subunit (Nygard and Nika 1982). This observation, together with the notion that phosphorylated $40 \mathrm{~S}$ ribosomal subunits form initiation complexes more efficiently (Duncan and McConkey 1982), led to the hypothesis that rpS6 phosphorylation might be involved in control of initiation of translation (Thomas et al. 1982). In order to directly examine the involvement of rpS6 phosphorylation in the control of global protein synthesis, we monitored the proportion of ribosomes that sedimented in the polysome region upon sucrose gradient centrifugation. Figure 3A shows that $74 \% \pm 3 \%(n=4)$ and $75 \% \pm 2 \%(n=4)$ of ribosomal particles from livers of untreated $\mathrm{rpS}^{\mathrm{P}+/+}$ and $\mathrm{rpS}^{\mathrm{P}-/-}$ mice, respectively, were engaged in polysomes, whereas these figures were $71 \% \pm 2 \%(n=4)$ and $74 \% \pm 1 \%(n=4)$, respectively, in regenerating livers. These results clearly indicate that elimination of all phosphorylatable sites in rpS6 does not impair the engagement of ribosomes in polysomes.

Next, we measured the rate of protein synthesis in $\mathrm{rpS}^{\mathrm{P}+/+}$ and $\mathrm{rpS}^{\mathrm{P}-/-}$ cells by monitoring the incorporation of $\left[{ }^{35} \mathrm{~S}\right]$ methionine and $\left[{ }^{35} \mathrm{~S}\right]$ cysteine into total cytoplasmic proteins. Surprisingly, not only was the incorporation not abrogated in $\mathrm{rpS}^{\mathrm{P}-/-}$ cells, it was stimulated by a factor of 2.5 (Fig. 3B). One plausible explanation for the enhanced incorporation of radioactive amino acids into proteins in $\mathrm{rpS6}^{\mathrm{P}-/-} \mathrm{MEFs}$ is a smaller pool of free amino acids and consequently a higher specific activity of the labeled amino acids in these cells, rather than the result of accelerated protein synthesis. To distinguish between these two possibilities, we monitored protein accumulation in both cell types. Figure 3C shows that steady-state accumulation of proteins in $\mathrm{rpS6}^{\mathrm{P}-/-}$ MEFs is 1.4-fold faster than in wild-type MEFs, thus underscoring the superiority of the former in protein synthesis.

To examine whether the enhanced protein synthesis in $\mathrm{rpS}^{\mathrm{P}-/-}$ cells results from accelerated peptide chain elongation, we determined the ribosome half-transit time (Fan and Penman 1970). This was performed by measuring the kinetics of radioactive amino acid incorporation into total protein in post-mitochondrial supernatant (PMS) and into completed polypeptides released
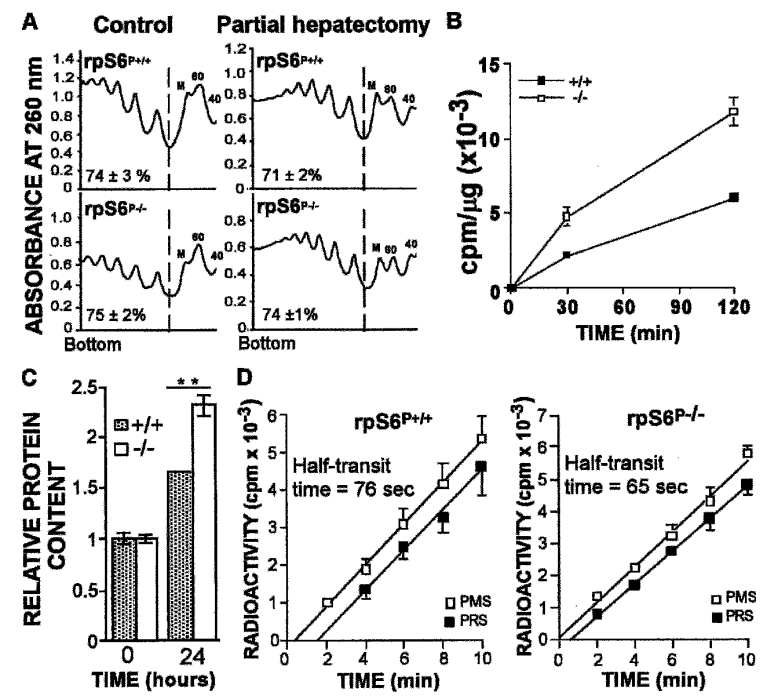

Figure 3. The effect of phosphorylatable serine deficiency in rpS6 on global protein synthesis in liver and MEFs. $(A) \mathrm{rpS}^{\mathrm{P}+/+}$ and $\mathrm{rpS}^{\mathrm{P}-/-}$ male mice underwent partial hepatectomy, and 23 $\mathrm{h}$ later cytoplasmic extracts were prepared from the remaining liver (Partial hepatectomy) or from livers of untreated mice (Control). These extracts were size-fractionated by centrifugation through sucrose gradients, and the absorbance of polysomes and subpolysomal particles was continuously monitored at $260 \mathrm{~nm}$. (M) Monosomes; (60) 60S subunits; (40S) 40S subunit. The vertical dashed line separates the polysomal fraction (left) and the subpolysomal fraction (right). The areas under the curve within these fractions were estimated by weighing paper cutouts of the profiles. The proportion of the area in the polysomal fraction has been referred to as the percentage of ribosomes engaged in translation. The results are presented as a mean $\pm \operatorname{SEM}(n=4)$. $(B) \mathrm{rpS}^{\mathrm{P}+/+}$ and $\mathrm{rpS}^{\mathrm{P}-/-}$ MEFs were pulselabeled with $\left[{ }^{35} \mathrm{~S}\right]$ methionine and $\left[{ }^{35} \mathrm{~S}\right]$ cysteine, and the protein synthesis was measured and presented as described in Materials and Methods. Protein synthesis at each time point for each cell type represents a mean $\pm \operatorname{SEM}(n=3) .(C)$ Growing $\mathrm{rpS}^{\mathrm{P}+/+}$ and rpS6 $^{\mathrm{P}-/-}$ MEFs (passage 2) were harvested at time 0 and $24 \mathrm{~h}$ later. Cells were lysed, and protein concentration in extracts was determined as described in Materials and Methods. The protein content at time 0 was arbitrarily set at 1 , and that of 24 $\mathrm{h}$ was normalized to this value. Results are presented as a mean \pm SEM $(n=3) .\left(^{\star \star}\right) P<0.001$ versus $\mathrm{rpS}^{\mathrm{P}+/+}$ MEFs. $(D)$ The ribosome half-transit time in $\mathrm{rpS6}^{\mathrm{P}+/+}$ and $\mathrm{rpS}^{\mathrm{P}-/-}$ MEFs was determined as described in Materials and Methods. Incorporation of $\left[{ }^{3} \mathrm{H}\right]$ leucine into total protein within the PMS and PRS was obtained by linear regression analysis. The radioactivity at each time point is presented as a mean $\pm \operatorname{SEM}(n=3$ and 5 for $\mathrm{rpS}^{\mathrm{P}+/+}$ and $\mathrm{rpS}^{\mathrm{P}-/-}$ MEFs, respectively).

from the ribosome in post-ribosomal supernatant (PRS). The average half-transit time was determined from the displacement in time between the two lines corresponding to the PMS and PRS data plotted as a function of time (Fig. 3D), and was calculated to be 76 and $65 \mathrm{sec}$, for $\mathrm{rpS6}^{\mathrm{P}+/+}$ and $\mathrm{rpS6}^{\mathrm{P}-/-} \mathrm{MEFs}$, respectively. The small decrease $(14 \%)$ in the half-transit time of the mutant ribosomes, although reflecting a slight increase in the elongation rate, cannot account for the 1.4-fold increase in the rate of protein accumulation in $\mathrm{rpS}^{\mathrm{P}-/-}$ MEFs (Fig. 3C). 
Taken together, the experiments with whole animals and MEFs indicate that phosphorylatable serine residues in rpS6 are dispensable for global protein synthesis in the liver and are inhibitory in MEFs. The mechanism underlying the enhanced protein synthesis in $\mathrm{rpS}^{\mathrm{P}-/-} \mathrm{MEFs}$ involves mostly the initiation step, yet its exact nature has yet to be determined.

\section{rpS6 phosphorylation sites are a determinant of cell size}

Drosophila cells lacking dS6K have been shown to be smaller than wild-type cells (Montagne et al. 1999). However, the relevant effector that is involved in the regulation of cell size has remained obscure. We therefore, set out to examine whether the phosphorylatable serine residues in rpS6 are a determinant of cell size. To this end, $\mathrm{rpS}^{\mathrm{P}-/-}$ and $\mathrm{rpS}^{\mathrm{P}+/+}$ MEFs were analyzed for cell size, using the parameter mean forward scatter height (FSC-H), which is a measure of relative cell size. Figure $4 \mathrm{~A}$ shows that $\mathrm{rpS}^{\mathrm{P}-/-} \mathrm{MEFs}$ are $24 \%$ smaller than $\mathrm{rpS}^{\mathrm{P}+/+}$ MEFs. Interleukin 7 (IL-7)-dependent cells, derived from fetal livers at day 14 of gestation and maintained in culture for $10 \mathrm{~d}$, were subjected to flow cytometry. This analysis demonstrated that $\mathrm{rpS6}^{\mathrm{P}-/-}$ IL-7-dependent cells were $19 \%$ smaller than wild-type cells ( $n=4$ for each genotype) (data not shown). Apparently, the smaller size of both these type of cells is not reflected in the size of newborn $\mathrm{rpS}^{\mathrm{P}-/-}$ mice, whose weights between day 1 and day 32 are indistinguishable from that of their wild-type littermates (Fig. 4B). One plausible explanation for the lack of impact of the size of these cells on the birth weight of the respective mice is a faster proliferation, which compensates for the smaller size of these cells. This possibility accords with the higher rate of protein accumulation observed in $\mathrm{rpS6}^{\mathrm{P}-/-}$ MEFs (Fig. $3 \mathrm{C})$. Indeed, the population doubling time $\left(t_{\mathrm{d}}\right)$ of $\mathrm{rpS}^{\mathrm{P}-l-}$ MEFs is significantly shorter than that of $\mathrm{rpS}^{\mathrm{P}+/+}$ MEFs (19.6 h and 31.6 h, respectively, in Fig. 4C). Notably, a similar discrepancy was measured also for the doubling time of steady-state levels of total proteins $(20.8 \mathrm{~h}$ and 29 h, respectively, in Fig. 3C) and nucleic acids (20.5 and 28.7, respectively, in Fig. 5F).

To determine what part of the cell cycle is shortened in rpS6 ${ }^{\mathrm{P}-/-}$ MEFs, we performed flow cytometry on asynchronous MEF cultures, using DNA content as a sorting parameter. The percentage of $\mathrm{rpS}^{\mathrm{P}-/-} \mathrm{MEFs}$ in G1 phase decreased from 53.5 in $\mathrm{rpS6}^{\mathrm{P}+/+}$ MEFs to 41.6 in rpS6 ${ }^{\mathrm{P}-/-}$ MEFs (Fig. 4D). This change reflects a shortening of the G1 phase from $16.4 \mathrm{~h}$ [percent in $\mathrm{G} 1 \times \mathrm{t}_{\mathrm{d}}$ ] in wild-type MEFs to $8.2 \mathrm{~h}$ in rpS6 ${ }^{\mathrm{P}-/-}$ MEFs, which can account for most of the apparent difference in the doubling times between these cell types. Finally, if the faster division rate of cells in $\mathrm{rpS}^{\mathrm{P}-l-}$ embryos compensates for their smaller size, then the number of cells in $\mathrm{rpS6}^{\mathrm{P}-/-}$ newborns might exceed that of wild-type newborns. Indeed, Figure 4E shows that the DNA content of the former was $15 \%$ higher than that of the latter $(3.074 \pm 0.064[n=4]$ and $2.681 \pm 0.11[n=4]$ micrograms of DNA per gram of body weight, respectively).
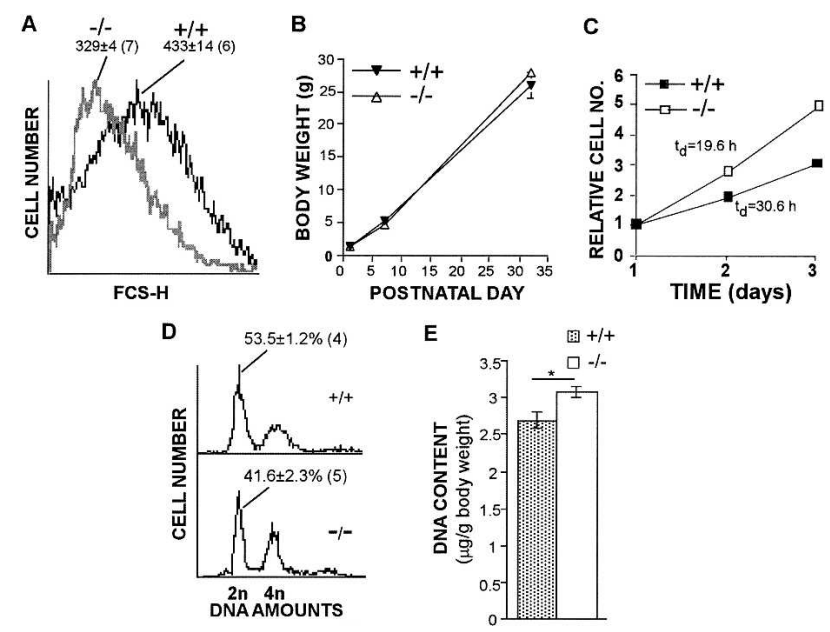

Figure 4. $\mathrm{rpS}^{\mathrm{P}-/-} \mathrm{MEFs}$ are smaller, yet they divide faster than the wild-type MEFs. (A) The size of nonsynchronous $\mathrm{rpS}^{\mathrm{P}+/+}$ (black curve) and rpS6 ${ }^{\mathrm{P}-1-} \mathrm{MEFs}$ (gray curve) was determined as described in Materials and Methods. The average size is presented as the mean FSC-H \pm SEM of the number of cultured plates in parenthesis. (B) Mean body weight of $\mathrm{rpS}^{\mathrm{P}+/+}$ and rpS6 ${ }^{\mathrm{P}-1-}$ mice $(n=13$ and 14 , respectively, for day $1 ; 12$ and 13 , respectively, for day 7; and 7 and 5, respectively, for day 32). Mice represent two distinct ES clones and are siblings from 11 pairs of heterozygous matings. $(C) \mathrm{rpS6}^{\mathrm{P}+/+}$ and $\mathrm{rpS6}^{\mathrm{P}-/-} \mathrm{MEFs}$ were seeded in a 24-well plate and, at the indicated time, cells were trypsinized and counted. The numbers of cells (average of four wells for each time point) were normalized to the number at time 0 , which was arbitrarily set at $1 .(D)$ The DNA content of $\mathrm{rpS}^{\mathrm{P}+/+}$ and $\mathrm{rpS6}^{\mathrm{P}-/-}$ MEFs was determined on a flow cytometer. Results are depicted as histograms with numerical values representing the percentage of cells in G1 (average \pm SEM). Propidium iodide positive staining is graphed on the $X$-axis with cell number on the $Y$-axis. (E) Mice (four of each genotype) were sacrificed $24 \mathrm{~h}$ post-partum, and the total DNA content was measured as described in Materials and Methods. Data are presented as micrograms of DNA/gram of body weight. Vertical bars represent SEM. $\left(^{\star}\right) P<0.01$ versus $\mathrm{rpS6}^{\mathrm{P}+/+}$ mice.

The small-size phenotype of $\mathrm{rpS}^{\mathrm{P}-/-}$ MEFs can result from an accelerated cell cycle in the face of an unchanged rate of cell growth. Under such circumstances, blocking cell division in the presence of nutrients should eliminate the size difference between $\mathrm{rpS}^{\mathrm{P}+/+}$ and rpS6 $6^{\mathrm{P}-/-}$ MEFs. This difference will remain, however, if $\mathrm{rpS6}^{\mathrm{P}-1-}$ MEFs are defective in their growth capacity. In order to distinguish between these two possibilities, we disconnected cell growth from cell cycle progression by $24 \mathrm{~h}$ of treatment with $30 \mu \mathrm{M}$ aphidicolin (DNA polymerase- $\alpha$ inhibitor), which completely arrested cell division (Fig. 5A). This treatment elicited a small increase in the size of $\mathrm{rpS6}^{\mathrm{P}+/+}$ and $\mathrm{rpS}^{\mathrm{P}-/-} \mathrm{MEFs}(9 \%$ and $6 \%$, respectively), yet the latter remained $21 \%$ smaller than the former ( $381 \pm 9$ and $483 \pm 3$ FSC-H units, respectively, in Fig. 5B). To further examine this issue, we monitored the cell size and cell doubling time of immortalized $\mathrm{rpS}^{\mathrm{P}+/+}$ and $\mathrm{rpS}^{\mathrm{P}-/-}$ MEFs. Figure $5 \mathrm{C}$ shows that the size of immortalized $\mathrm{rpS}^{\mathrm{P}-/-}$ MEFs increased to the extent that it equalized with that of $\mathrm{rpS}^{\mathrm{P}+/+}$ MEFs (456 \pm 6 and 

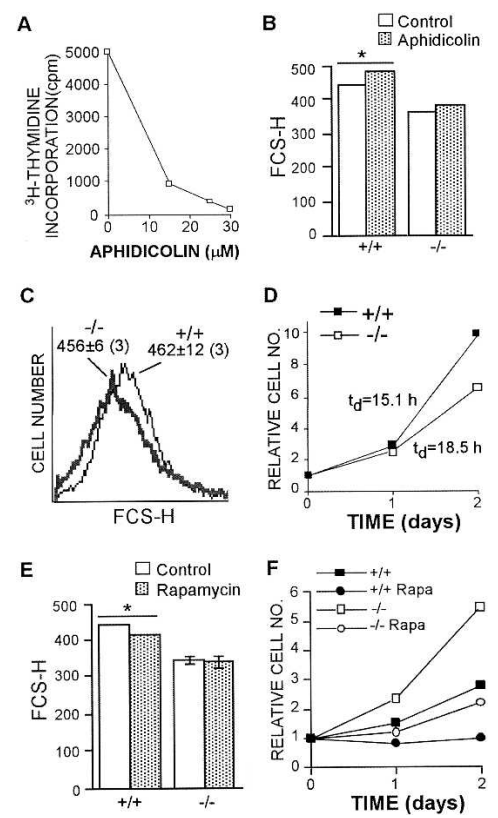

Figure 5. The smaller size of $\mathrm{rpS}^{\mathrm{P}-/-}$ MEFs is not a by-product of their faster cell division. (A) MEFs (passage 3) were seeded in a 96-well plate at a density of $20 \times 10^{3}$ per well. On the following day, cells were treated for $24 \mathrm{~h}$ with increasing concentrations of aphidicolin, and ${ }^{3} \mathrm{H}$-thymidine incorporation during the last $3 \mathrm{~h}$ was measured as described in Materials and Methods. Each point represents an average value of four wells. (B) $\mathrm{rpS}^{\mathrm{P}+/+}$ and $\mathrm{rpS}^{\mathrm{P}-/-} \mathrm{MEFs}$ (passage 3) were either untreated (Control) or treated with $30 \mu \mathrm{M}$ aphidicolin for $24 \mathrm{~h}$, and their size was determined as described in Materials and Methods. The average size is presented as the mean FSC-H $\pm \operatorname{SEM}(n=4) .\left(^{*}\right) P<0.01$ versus untreated cells. $(C)$ The size of nonsynchronous immortalized rpS6 ${ }^{\mathrm{P}+/+}$ (black curve) and $\mathrm{rpS6}^{\mathrm{P}-/-}$ MEFs (gray curve) was determined as described in Materials and Methods. The average size is presented as the mean FSC-H \pm SEM of the number of cultured plates in parentheses. (D) Immortalized MEFs were seeded in 96-well plates at a density of $4 \times 10^{3}$ per well. Proliferation was monitored by measuring the $\mathrm{A}_{650}$ of the methyleneblue dye extracted from stained cells (Oliver et al. 1989). Absorbance measured $6 \mathrm{~h}$ after platting was set arbitrarily at 1 , and absorbance measured at later time points (average \pm SEM; $n=12$ for each time point) was normalized to that value. (E) $\mathrm{rpS6}^{\mathrm{P}+/+}$ and $\mathrm{rpS6}^{\mathrm{P}-/-}$ MEFs (passage 3) were either untreated (Control) or treated with $20 \mathrm{nM}$ rapamycin for $48 \mathrm{~h}$, and their size was determined as described in Materials and Methods. The average size is presented as a mean FSC- $\mathrm{H} \pm \operatorname{SEM}(n=3) .\left(^{\star}\right)$ $P<0.05$ versus untreated cells. $(F) \mathrm{rpS}^{\mathrm{P}+/+}$ and $\mathrm{rpS}^{\mathrm{P}-/-}$ MEFs (passage 3) were either untreated or treated with $20 \mathrm{nM}$ rapamycin for $48 \mathrm{~h}$ (Rapa), and the rate of proliferation was measured as described in $D$. Each time point is an average \pm SEM $(n=6$ to 12). The bars representing the SEM in $D$ and $F$ are smaller than the symbols' size.

$462 \pm 12$ FSC-H units, respectively). However, this increase in size was not accompanied by lengthening of the $t_{\mathrm{d}}$ (Fig. 5D), as would be expected if the size was inversely proportional to the division rate. Likewise, immortalization led to a twofold shortening of the doubling time of wild-type MEFs (from $30.6 \mathrm{~h}$ before [Fig. 4C] to $15.1 \mathrm{~h}$ after [Fig. 5D] immortalization). Yet, despite this acceleration in their proliferation rate, their size did not decrease (433 and 462 FSC-H units before [Fig. 4A] and after [Fig. 5C] immortalization, respectively). Taken together, these results lend support to the notion that the small-size phenotype of primary $\mathrm{rpS}^{\mathrm{P}-/-}$ MEFs reflects impaired growth, rather than being a by-product of accelerated cell division.

\section{Rapamycin failed to decrease the size of $\mathrm{rpS6}^{\mathrm{P-} /-}$ $M E F S$}

Previous reports have demonstrated that treatment of mammalian cells by rapamycin, an mTOR inhibitor, decreases their size. This mTOR-dependent regulation of the cell size involves its downstream targets, S6K1 and 4E-BP (Fingar et al. 2002; Ohanna et al. 2005). Here we show that the size of $\mathrm{rpS}^{\mathrm{P}+/+}$ MEFs decreased by $9 \%$ upon rapamycin treatment, whereas the size of $\mathrm{rpS}^{\mathrm{P}-/-}$ MEFs was unaffected by this treatment (Fig. 5E). It should be noted, however, that the apparent rapamycin resistance of $\mathrm{rpS}^{\mathrm{P}-/-}$ MEFs is confined to the effect of this drug on the cell size, as their proliferation rate was significantly reduced by rapamycin treatment, albeit to a lesser extent than that of wild-type MEFs (Fig. 5F).

\section{Glucose homeostasis is compromised in $\mathrm{rpS6}^{P-/-}$ mice}

It has previously been shown that insulin secretion closely correlates with the size of $\beta$-cells (Giordano et al. 1993; Pende et al. 2000). Mice deficient for S6K1 exhibited impaired glucose homeostasis, due to insufficient insulin secretion in response to glucose load. The reason for this defect was proposed to be the small size of $\beta$-cells in S6K1 ${ }^{-1-}$ mice (Pende et al. 2000). Neither rpS6 nor any of the other potential S6K1 substrates has been implicated in this defect. To directly address this issue, we first set out to examine whether the phosphorylatable serine residues in rpS6 play a role in size regulation of $\beta$-cells. To this end, pancreatic sections were subjected to immunostaining and morphometry. DAPI staining of nuclei in such sections demonstrated a greater density of cells in islets from $\mathrm{rpS}^{\mathrm{P}-/-}$ mouse than in wild-type islets (Fig. 6A,B). Accordingly, the higher density is reflected in an apparent smaller cytoplasmic volume of $\beta$-cells, as exemplified by insulin immunostaining of the same islets (Fig. 6C,D). Measuring the density of $\beta$-cells in a constant area within multiple islets indicated that insulin-positive cells were more densely packed in rpS6 ${ }^{\mathrm{P}-/-}$ islets (Fig. 6E). This difference implies that the average section area and volume of an $\mathrm{rpS}^{\mathrm{P}-/-} \beta$-cell are $25 \%$ and $35 \%$, respectively, smaller than those of the wild-type counterpart. Similar results were obtained when the total number of $\beta$-cells, in 10 islets from each genotype, was normalized to the entire area occupied by these cells in each islet (data not shown). Evidently, the reduced size of $\beta$-cells is specific, as the density of $\mathrm{rpS6}^{\mathrm{P}-/-}$ acinar cells, which comprise most of the pancreatic mass, is similar to that of the wild-type cells (Fig. $6 \mathrm{~F})$. Likewise, a similar size of $\mathrm{T}$ lymphocytes, derived 

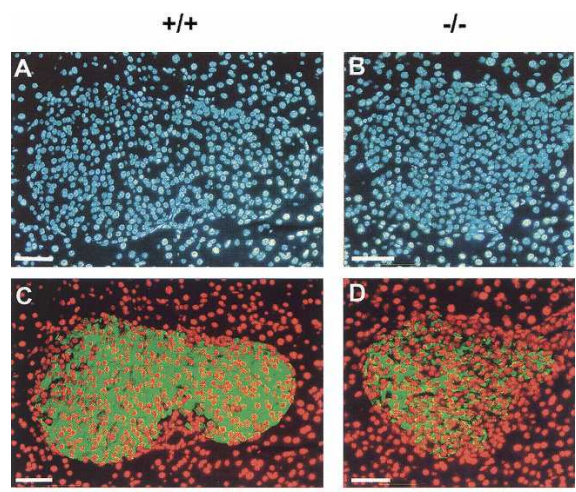

E

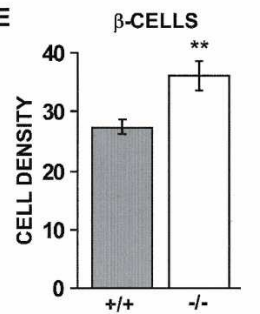

F

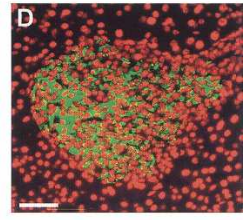

$\mathbf{F}$

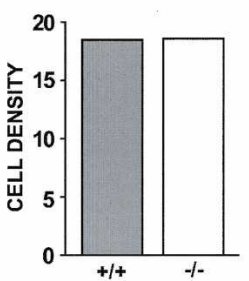

Figure 6. Pancreatic $\beta$-cells are selectively smaller in $\mathrm{rpS}^{\mathrm{P}-/-}$ mice. Pancreatic sections from $\mathrm{rpS}^{\mathrm{P}+/+}$ and $\mathrm{rpS}^{\mathrm{P}-/-}$ mice were stained for DNA by DAPI (blue in $A, B$, red in $C, D$ ) and for insulin (green in $C, D$ ). Panels $C$ and $D$ represent insertion of the RGB image from the DAPI staining into the red channel of the respective image of the insulin staining. Shown are representative islets. Bar, $50 \mu \mathrm{m}$. The density of $\beta$-cells $(E)$ and acinar cells $(F)$ was assessed by counting the number of nuclei in multiple $2500-\mu \mathrm{m}^{2}$ squares within islets that contain only insulin-positive cells or within exocrine pancreas that contains only acinar cells, respectively. Values are presented as a mean \pm SEM of $\sim 100$ determinations done with five to seven islets for each cell type in four female mice of each genotype. $\left(^{\star \star}\right) P<0.001$ versus rpS6 $6^{\mathrm{P}+/+}$ mice.

from lymph nodes of adult $\mathrm{rpS}^{\mathrm{P}-/-}$ or $\mathrm{rpS}^{\mathrm{P}+/+}$ mice and activated with anti-CD3 and anti-CD28, was measured by flow cytometry (data not shown). It appears, therefore, that normal growth of $\beta$-cells is more reliant on the phosphorylatable serine residues than growth of other examined cell types in the adult mouse.

Next, we asked whether the impaired glucose homeostasis, which was described for S6K1 knockout mice (Pende et al. 2000), could also be attributed to a defect in rpS6 phosphorylation. Figure 7A shows that the blood glucose level in fasted $\mathrm{rpS}^{\mathrm{P}-/-}$ mice $177 \pm 4 \mathrm{mg} / \mathrm{dL}$, $n=14)$ was quite similar to that of $\mathrm{rpS}^{\mathrm{P}+/+}$ mice $(75 \pm 5$ $\mathrm{mg} / \mathrm{dL}, n=11)$. However, the mutant mice exhibited significant reduction in their glucose disposal capacity, as exemplified by the higher and prolonged hyperglycemic response following a glucose challenge (Fig. 7A). This impairment might reflect reduced glucose uptake by peripheral tissues and/or pancreatic failure. Figure $7 \mathrm{~B}$ shows that in the fasting state, $\mathrm{rpS}^{\mathrm{P}-/-}$ mice had significantly lower serum insulin concentrations than the wild-type mice $\left(\mathrm{rpS}^{\mathrm{P}+/+}\right.$ mice $388 \pm 51 \mathrm{pg} / \mathrm{mL}^{\text {; }} \mathrm{rpS}^{\mathrm{P}-/-}$ mice, $171 \pm 22 \mathrm{pg} / \mathrm{mL} ; P<0.01)$. Measurement of pancreatic insulin of age-matched female $\mathrm{rpS}^{\mathrm{P}+/+}$ and $\mathrm{rpS}^{\mathrm{P}-/-}$ mice revealed a twofold decrease in total insulin content in the pancreas of knock-in mice relative to that of wildtype mice (Fig. 7C). An intriguing question is whether the lower content of pancreatic insulin reflects reduced total $\beta$-cell mass. To draw a quantitative assessment of this latter parameter, we subjected multiple sections of each pancreas to immunostaining and morphometry. The results presented in Figure 7D clearly show that the total $\beta$-cell mass is similar in the pancreas of both genotypes. Moreover, this similarity implies an increase by a factor of $\sim 1.5$ in the number of $\beta$-cells in $\mathrm{rpS}^{\mathrm{P}-/-}$ mice in order to compensate for their smaller size. Hence, the overall reduction in insulin content by a factor of 2 seems to reflect a decrease by about threefold in the rate of insulin accumulation per cell.

Finally, to determine whether the hypoinsulinemia is accompanied by alterations in insulin resistance, we carried out insulin tolerance tests. Figure 7E demonstrates that not only did the peripheral tissues in the knock-in
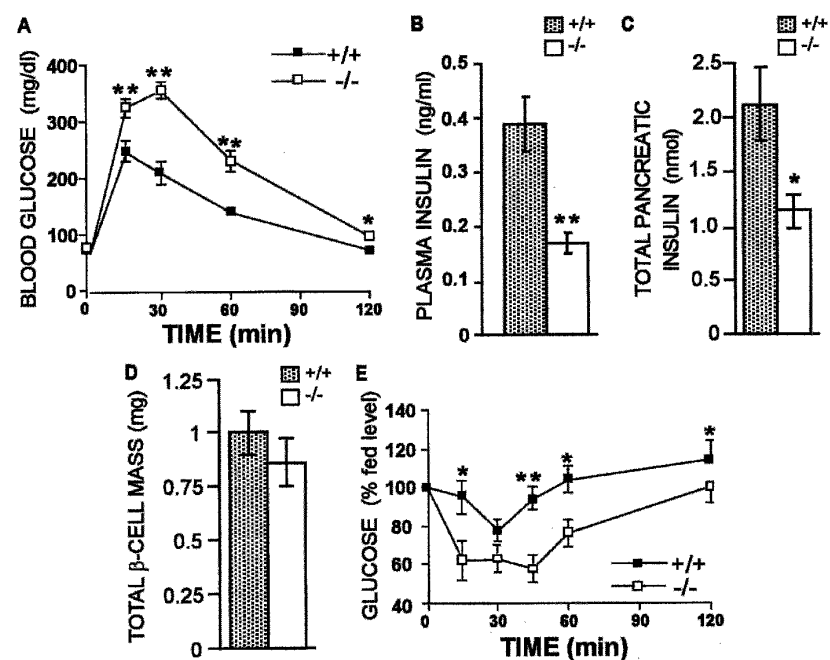

Figure 7. Glucose homeostasis is damaged in $\mathrm{rpS}^{\mathrm{P}-/-}$ mice. (A) Glucose tolerance test. Blood glucose concentrations before and after intraperitoneal injection of $2.5 \mathrm{~g}$ of D-glucose per kilogram of body weight in 6-wk-old mice fasted for $17 \mathrm{~h}$. The data represent an average \pm SEM for $11 \mathrm{rpS}^{\mathrm{P}+/+}$ mice (four males and seven females) and $14 \mathrm{rpS}^{\mathrm{P}-1-}$ mice (nine males and five females), respectively. $\left(^{\star}\right) P<0.05 ;\left(^{\star \star}\right) P<0.005$ versus $\mathrm{rpS}^{\mathrm{P}+/+}$ mice. $(B)$ Insulin concentrations in 2-mo-old female mice fasted for $16 \mathrm{~h}$ were determined by tail bleeding. Values depict an average \pm SEM for seven animals each. $\left({ }^{\star *}\right) P<0.005$ versus rpS6 ${ }^{\mathrm{P}+++}$ mice. $(C)$ Total pancreatic insulin content. Pancreases from age-matched female mice were removed, and the insulin content was measured as described in Materials and Methods. The data represent an average \pm SEM for five animals each. $\left(^{\star}\right)$ $P<0.05$ versus $\mathrm{rpS}^{\mathrm{P}+/+}$ mice. $(D)$ Total $\beta$-cell mass. Pancreases from four $\mathrm{rpS}^{\mathrm{P}+/+}$ and seven $\mathrm{rpS}^{\mathrm{P}-/-}$ age-matched female mice were removed, and the total $\beta$-cell mass was determined as described in Materials and Methods. The data are presented as a mean \pm SEM. $(E)$ Insulin tolerance test. Blood glucose concentrations before and after intraperitoneal injection of $0.25 \mathrm{U}$ of insulin/kilogram of body weight in 2-mo-old fed female mice. The data represent an average \pm SEM for five animals each. $\left(^{*}\right)$ $P<0.05 ;\left(^{\star \star}\right) P<0.005$ versus $\mathrm{rpS6}^{\mathrm{P}+/+}$ mice. 
mice not display insulin-resistance, they actually exhibited greater sensitivity, as exemplified by the greater glucose-lowering effect.

It appears, therefore, that the diminished glucose disposal capacity of $\mathrm{rpS}^{\mathrm{P}-/-}$ mice primarily reflects relative insulin deficiency, rather than insulin resistance in peripheral tissues. Taken together, our results clearly show that the phosphorylatable serine residues in $\mathrm{rpS} 6$ are critical for the normal size and function of $\beta$-cells, as well as the insulin sensitivity in peripheral tissues. Moreover, these observations imply that $\mathrm{rpS} 6$ is the prime substrate through which S6K1 exerts its effect on glucose homeostasis.

\section{Discussion}

The first attempt to elucidate the role of $\mathrm{rpS} 6$ phosphorylation was carried out in yeast, whose rpS6, like its mammalian counterpart, is phosphorylated upon mitogenic stimulation, yet at only two serine residues. Serine-toalanine substitution of these phosphorylatable residues had no detectable effect on yeast growth under a wide variety of nutritional conditions (Johnson and Warner 1987). In light of this observation, the physiological role of yeast rpS6 phosphorylation has so far remained obscure. Interestingly, conditional knockout of both alleles of rpS6 in adult mouse liver has demonstrated the requirement for this protein for ribosome assembly and therefore for cell proliferation, but not for cell growth (Volarevic et al. 2000). The present report, however, for the first time provides evidence that the phosphorylatable serine residues in mouse $\mathrm{rpS} 6$ are necessary for regulation of the size of at least some cell types, and that the smaller size of $\beta$-cells is associated with impaired glucose homeostasis.

\section{rpS6 phosphorylation and cell size}

Recent studies have demonstrated that cell cycle progression and cell growth are separable and are therefore distinct processes, at least in some mammalian cells (for review, see Conlon et al. 2004; Fingar and Blenis 2004). Thus, overexpression of S6K1 or initiation factor 4E (eIF$4 \mathrm{E})$ resulted in increased cell size, due to augmented cell growth and not from delayed cell cycle progression (Fingar et al. 2002). Likewise, overexpression of c-Myc in serum-starved B-cells or aphidicolin treatment of Schwann cells accelerated their growth independent of cell division (Schumacher et al. 1999; Conlon et al. 2001). Conversely, the decreased cell size observed upon overexpression of 4E-BP1 resulted from decreased cell growth and not from accelerated cell cycle progression (Fingar et al. 2002). Similarly, the small-size phenotype of S6K1 ${ }^{-/-}$myoblasts and $\mathrm{ppS}^{\mathrm{P}-/-}$ MEFs appears to result primarily from a defect in their growth (Ohanna et al. 2005; this study). Furthermore, the small, yet statistically significant, decrease in the size of rapamycintreated $\mathrm{rpS}^{\mathrm{P}+/+}$ MEFs (Fig. 5E) is similar to that reported for rapamycin-treated U2OS and HEK 293 cells (Fingar et al. 2002), whereas the rapamycin resistance displayed by rpS6 ${ }^{\mathrm{P}-1-}$ MEFs is reminiscent of that exhibited by S6K1 $1^{-/-}$myoblasts (Ohanna et al. 2005). It appears, therefore, that rpS6 phosphorylation is a critical effector of mTOR in regulation of cell growth. Notably, the small size of S6K1 $1^{-/-}$myoblasts is apparent, even though their rpS6 is still phosphorylated, most probably by $\mathrm{S} 6 \mathrm{~K} 2$ (Ohanna et al. 2005). Conceivably, once the growth of a specific cell lineage is blocked by a temporary deficiency of rpS6 phosphorylation, as a result of S6K1 deficiency, the small size is maintained thereafter, regardless of a later phosphorylation of rpS6 by a different kinase.

The smaller size of $\beta$-cells in $\mathrm{rpS}^{\mathrm{P}-/-}$ islets might also result from selective decreased cell growth. However, in the absence of data regarding the rate of division of these cells, we cannot exclude the possibility that their smaller size is secondary to an accelerated division. It appears, however, that the small cell phenotype is confined to only a subset of cells. Thus, either acinar cells in the pancreas (Fig. 6) or activated T lymphocytes from lymph nodes (data not shown) displayed a similar size regardless of the rpS6 genotype. Interestingly, the similar total $\beta$-cell mass in both genotypes, despite the smaller size of individual $\beta$-cells in $\mathrm{rpS}^{\mathrm{P}-/-}$ islets, suggests that this tissue operates a mass-control mechanism rather than monitoring cell number. Likewise, the similar birth weight of $\mathrm{rpS}^{\mathrm{P}-/-}$ mice (Fig. 4B), despite a smaller size of embryonic cells from these mice (Fig. 4A), suggests that a similar mechanism functions also at the organismal level.

Mammalian rpS6 is phosphorylated in response to multiple external signals, which are transduced through the phosphatidylinositol 3-kinase (PI3-kinase)/mTOR pathway(s) (for review, see Fingar and Blenis 2004; Hay and Sonenberg 2004). Genetic and biochemical studies have demonstrated that all constituents of these two pathways, examined thus far are involved in the size regulation of mammalian cells (for review, see Fingar and Blenis 2004). Interestingly, transgenic mice, which overexpress active Akt1 specifically in their $\beta$-cells, display an increase in both the number and size of their $\beta$-cells (Bernal-Mizrachi et al. 2001; Tuttle et al. 2001). It should be noted that constitutive activation of Akt1 by its targeting to the membrane, as conducted in both these studies, leads to constitutive activation of S6K1 (Burgering and Coffer 1995). The apparent opposite effects on $\beta$-cell size of constitutively active Akt 1 , on the one hand, and of deficiency of S6K1 or rpS6 phosphorylation (Pende et al. 2000; this study), on the other hand, suggest that Akt1 induces enlargement of $\beta$-cells, at least partly, by activation of rpS6 phosphorylation.

\section{rpS6 phosphorylation and glucose homeostasis}

We have observed a twofold reduction in circulating insulin levels in $\mathrm{rpS6}^{\mathrm{P}-/-}$ mice in comparison to wild-type mice (Fig. 7B). This decrease is similar to that reported for S6K ${ }^{-1-}$ mice (Pende et al. 2000), and might reflect diminished accumulation in and/or secretion from $\beta$-cells. Indeed, $\beta$-cell size is known to have a pro- 
nounced effect on insulin secretion, such that a $35 \%$ reduction in cell size, as reported here, can lead to a $40 \%-50 \%$ reduction in insulin secretion (Giordano et al. 1993). However, even though the relative radius of these cells, as calculated from their relative density (Fig. $6 \mathrm{E}$ ), is $25 \%$ smaller than that of the wild-type cells, the 1.5 -fold higher number of the former renders their total surface area a nonlimiting parameter. It appears, therefore, that the decreased pancreatic insulin content, and possibly an impaired mechanism of insulin secretion, accounts for the apparent lesion in glucose homeostasis.

Interestingly, the apparent glucose intolerance in $\mathrm{rpS}^{\mathrm{P}-/-}$ mice is reminiscent of the impaired glucose tolerance observed in offspring of rats that were undernourished during pregnancy, or in adult human beings after prenatal exposure to famine (Ravelli et al. 1998 and references therein). Moreover, a low-protein diet during pregnancy leads to reduction of pancreatic cell proliferation, islet size, islet vascularization, and insulin content in the fetal rat (Dahri et al. 1991). Possibly, malnutrition during pregnancy leads to insufficient signals through mTOR, an integrator of nutritional signals (Fingar and Blenis 2004; Proud 2004), which in turn leads to hypophosphorylation of rpS6 during a critical stage of pancreatic development and consequently to impaired pancreatic function in the adult organism. It should be pointed out, however, that the effect of perinatal famine on the size of $\beta$-cells, a hallmark of $\mathrm{rpS6}^{\mathrm{P}-/-}$ and $\mathrm{S} 6 \mathrm{~K}^{-/-}$mice, is currently unknown. Consequently, assessment of the parallelism between these mutants and the starved embryos should wait till this information is available.

In addition to the pancreatic phenotype, $\mathrm{rpS}^{\mathrm{P}-/-}$ mice display increased insulin sensitivity in peripheral tissues (Fig. 7E), which is reminiscent of that observed in S6K1deficient mice (Pende et al. 2000). It has recently been proposed that S6K1 exerts a negative feedback loop on insulin receptor substrate 1 (IRS1) by phosphorylation of a serine residue, and thus blocks its signal transduction activity (Harrington et al. 2004; Um et al. 2004). However, if increased insulin sensitivity in $\mathrm{S} 6 \mathrm{~K}^{-1-}$ mice, indeed, results from the elimination of serine phosphorylation, it is quite puzzling how the lack of phosphorylatable serine residues in rpS6 is able to phenocopy the effect of S6K1 deficiency. One plausible explanation is that unphosphorylatable rpS6 is associated with an increased activity of an IRS1 serine phosphatase.

Notably, rpS6 in our knock-in mice not only cannot be phosphorylated but also contains five serine-to-alanine substitutions. Hence, it can be argued that the observed phenotype results from impeded ribosomal function due to these structural modifications, rather than being phosphorylation-free. Nonetheless, many of the phenotypic manifestations of $\mathrm{rpS}^{\mathrm{P}-/-}$ knock-in mice are similar to those observed in S6K1 knockout mice. These include smaller-size $\beta$-cells, diminished insulin content in pancreas, hypoinsulinemia, glucose intolerance, and insulin hypersensitivity in peripheral tissues (Pende et al. 2000; this study). This apparent similarity suggests that it is the failure to phosphorylate rpS6 that can account for the common defects in both types of mutants. Ac- cordingly, our results strongly imply that rpS6 is the missing effector of S6K1 in regulation of the size and function of $\beta$-cells. It should be stressed, however, that S6 $61^{-1-}$ mice, unlike $\mathrm{rpS6}^{\mathrm{P}-/-}$ mice, also display an in utero developmental defect manifested in smaller birth size (Shima et al. 1998), and the disruption of both S6K1 and S6K2 leads to decreased viability due to perinatal lethality (Pende et al. 2004). Clearly, these phenotypes indicate that $56 \mathrm{~K} 1$ and/or S6K2 exert their distinct effects via targets other than rpS6. Indeed, S6K has been implicated in an increasing list of cellular processes through a wide variety of newly established substrates (de Groot et al. 1994; Wilson et al. 2000; Harada et al. 2001; Wang et al. 2001; Harrington et al. 2004; Raught et al. 2004; Richardson et al. 2004).

\section{rpS6 phosphorylation and protein synthesis}

Our present results have established that rpS6 phosphorylation is dispensable for efficient translation of TOP mRNAs. This observation, together with the report that TOP mRNAs are efficiently translated in $\mathrm{S} 6 \mathrm{~K}^{-1-}$ $\mathrm{S} 6 \mathrm{~K} 2^{-1-}$ cells (Pende et al. 2004), has unambiguously demonstrated that translational activation of TOP mRNAs relies on neither S6K activity nor on rpS6 phosphorylation. It should be mentioned that rapamycin ubiquitously blocks the activation of S6K1 and S6K2 and rpS6 phosphorylation (Chung et al. 1992; Shima et al. 1998), and suppresses translational activation of TOP mRNAs in some cell lines (Stolovich et al. 2002 and references therein). However, the fact that TOP mRNAs are translationally controlled in an S6K- and rpS6-phosphorylation-independent fashion (Pende et al. 2004; this study) implies that mTOR or another, as yet unknown, rapamycin-sensitive target exerts its regulatory role on TOP mRNAs in an S6K1- and S6K2-independent fashion.

The data presented here have shown that rpS6 phosphorylation is dispensable for efficient polysomal association of liver ribosomes (Fig. 3A). Moreover, the rates of global protein synthesis and accumulation are even increased in $\mathrm{rpS}^{\mathrm{P}-1-}$ MEFs (Fig. 3B,C). This latter observation implies that protein synthesis, at least in this cell type, is down-regulated by rpS6 phosphorylation. Nevertheless, one plausible explanation for the discrepancy between the enhancements in the rates of protein synthesis and protein accumulation (2.5-fold and 1.4-fold higher, respectively, in $\mathrm{rpS}^{\mathrm{P}-/-} \mathrm{MEFs}$ ), is an increased protein degradation in the mutant cells, which partially counterbalances the higher synthesis rate. However, validation of this hypothesis should await further studies. Furthermore, the enhanced protein synthesis in $\mathrm{rpS}^{\mathrm{P}-/-}$ MEFs cannot be attributed to the slight increase in the rate of translation elongation, as measured in these cells (Fig. 3D). Likewise, it cannot be ascribed to activation of S6K kinase and/or inactivation of eIF-4Ebinding protein 1 (4E-BP1), as their phosphorylation in $\mathrm{rpS6}^{\mathrm{P}-{ }^{-}-}$MEFs was not higher than that detected in $\mathrm{rpS}^{\mathrm{P}+/+}$ MEFs (data not shown). Nonetheless, the tissuespecific deleterious effect in the pancreas of glucose- 
loaded $\mathrm{rpS}^{\mathrm{P}-/-}$ mice suggests that $\mathrm{rpS} 6$ phosphorylation is required for the synthesis or function of some critical proteins necessary for coping with hyperglycemia.

Conceivably, the phosphorylation of rpS6 increases the affinity of the $40 \mathrm{~S}$ ribosomal subunit to a subclass of mRNAs, and thus promotes their efficient translation. However, we cannot rule out the possibility that the phosphorylated rpS6 does not affect protein synthesis, but instead serves as a docking site for a protein(s), which consequently becomes active or inactive, and thus affects the cell physiology. It should be mentioned that rpS6 is not the only ribosomal protein that undergoes regulated phosphorylation. It has recently been shown that interferon- $\gamma$-dependent phosphorylation of $\mathrm{rpL13a}$ leads to its release from the 60S ribosomal subunit and subsequently to its binding to ceruloplasmin mRNA, and consequently to its silencing (Mazumder et al. 2003).

\section{Materials and methods}

Generation of $\mathrm{rpS6}^{P-/-}$ mice

A 6.85-kb DNA fragment, containing mouse rpS6 gene as well as 0.9 and $3.3 \mathrm{~kb}$ of $5^{\prime}$ - and $3^{\prime}$-flanking sequences, respectively, was assembled from two partially overlapping genomic clones, isolated (Pata and Metspalu 1996) from a 129Sv/J library (Stratagene). A targeting vector was constructed by inclusion of the following modifications: (1) substitution of 6 nucleotides (nt) within the coding sequence to yield replacement of all five phosphorylatable serine residues by alanine residues; (2) insertion of an EcoRV site $(5 \mathrm{nt})$ immediately downstream of the coding sequence; (3) conservative substitution $\mathrm{A} \rightarrow \mathrm{C}$ in the Arg233 codon, yielding an AatII site; (4) insertion of a neomycin-resistance gene $\left(n e o^{r}\right)$ driven by the phosphoglycerate kinase (PGK) promoter $0.4 \mathrm{~kb}$ downstream of the rpS6 gene; and (5) insertion of a diphtheria toxin A chain gene driven by the PGK promoter (a negative selectable marker), immediately upstream of the rpS6 genomic sequence to enable enrichment of correctly targeted clones (Fig. 1A). The targeting vector was linearized by NotI digestion and electroporated $(105 \mu \mathrm{g})$ into ES cells $\left(35 \times 10^{6}\right)$ from the R1 (129Sv $\times 129 \mathrm{~Sv}-\mathrm{CP})$ strain. The cells were grown in the presence of G418, and five correctly targeted clones were identified by Southern blot hybridization of genomic DNA, with two different probes (Fig. 1A). Three correctly targeted clones were aggregated with morulae-stage embryos to produce chimeras. Male chimeras were mated with ICR females to produce $\mathrm{rpS}^{\mathrm{P}+/-}$ offspring, which were intercrossed to produce $\mathrm{rpS6}^{\mathrm{P}-/-}$ mice. The rpS6 ${ }^{\mathrm{P}+/+}$ littermates obtained in these crosses are the ancestors of the wild-type mice used in this study. The resulting offspring were genotyped by Southern blot analysis using indicative probes (Fig. 1A), or PCR using primers spanning the mutated region: rpS6-52, 5'-GTCATCCAGCATGGGTG CTG-3'; and rpS6-11, 5'-GGCTGATACCTTTTGGGACAG-3'. The PCR product was digested with EcoRV to identify those carrying the mutant allele. Animal experiments were carried out in compliance with the Hebrew University guidelines.

\section{Mouse embryo fibroblasts}

MEFs were prepared from embryos at day 13.5 of gestation as described previously (Hogan et al. 1994). Immortalized MEFs were obtained by transfection with a plasmid expressing the Simian Virus 40 large T-antigen. Proliferating MEFs were tryp- sinized and resuspended in PBS, and the average cell size in 10,000-cell samples was assessed using the FACStar ${ }^{\text {plus }}$ flow cytometer (Becton Dickinson) with Cell Quest software. The resulting parameter, mean forward scatter height (FSC-H), is a measure of relative cell size. The division rate was determined by either counting trypsinized cells in a hemocytometer at intervals of $24 \mathrm{~h}$, or by the methylene-blue staining protocol $/ \mathrm{Ol}$ iver et al. 1989). DNA synthesis was measured by labeling cells grown in a 96-well plate with $1 \mu \mathrm{Ci}$ of $\left[{ }^{3} \mathrm{H}\right]$ thymidine (Amersham)/well. Cells were collected $3 \mathrm{~h}$ later with a cell harvester (Harvester96 MachIIIME; Tomtec), and radioactivity was measured with a 1450 MicroBeta Plus liquid scintillation counter (Wallac).

\section{$R T-P C R$}

Total RNA was isolated from ES cells with Ultraspec (Biotecx Laboratories). This RNA was subjected to RT-PCR using the AccessQuick RT-PCR System (Promega) and primers spanning the mutated region: rpS6-24, 5'-AGGAGGCTGCAGAATAC GCTAAAC-3'; and rpS6-51, 5'-GGTCATTATTTATTTGTT GCTC-3'.

\section{Partial hepatectomy}

Partial hepatectomy resulting in the removal of the median and left lateral lobes of the liver was performed on age-matched $\mathrm{rpS}^{\mathrm{P}+/+}$ and $\mathrm{rpS}^{\mathrm{P}-/-}$ male mice (6-13 wk old) under xylazine (10 $\mu \mathrm{g} / \mathrm{g}$ body weight) and ketamine ( $450 \mu \mathrm{g} / \mathrm{g}$ body weight) anesthesia.

\section{Determination of rpS6 phosphorylation}

Primary MEFs were serum starved for $48 \mathrm{~h}$ in $60-\mathrm{mm}$ plates, and then the medium was replaced with $0.5 \mathrm{~mL}$ of phosphate-free Dulbecco's Modified Eagle's Medium containing 10\% dialyzed fetal bovine serum. After $30 \mathrm{~min}$ of preincubation at $37^{\circ} \mathrm{C}$, cells were labeled with $20 \mu \mathrm{L}(200 \mu \mathrm{Ci})$ of $\left[{ }^{32} \mathrm{P}\right]$ orthophosphate $(8000$ $\mathrm{Ci} / \mathrm{mmol}$; Amersham) for $2 \mathrm{~h}$. Cells were pelleted at $2000 \mathrm{rpm}$ in a microfuge at $4^{\circ} \mathrm{C}$, resuspended in $150 \mu \mathrm{L}$ of resuspension buffer $\left(10 \mathrm{mM} \mathrm{NaCl}, 10 \mathrm{mM}\right.$ Tris- $\mathrm{HCl}$ at $\mathrm{pH} 7.4,15 \mathrm{mM} \mathrm{MgCl}_{2}$, $50 \mathrm{mM} \beta$-glycerophosphate, $20 \mathrm{mM}$ PMSF, $10 \mu \mathrm{g} / \mathrm{mL}$ aprotinin, and $10 \mu \mathrm{g} / \mathrm{mL}$ leupeptin) and lysed by adding $20 \mu \mathrm{L}$ of lysis buffer (10\% Triton X-100, 10\% deoxycholate). The cell lysate was centrifuged at $4^{\circ} \mathrm{C}$ for $2.5 \mathrm{~min}$ at $14,000 \mathrm{rpm}$. One-hundredfifty microliters of the supernatant were diluted with $350 \mu \mathrm{L}$ of polysomal buffer $\left(25 \mathrm{mM}\right.$ Tris- $\mathrm{HCl}$ at $\mathrm{pH} 7.4,10 \mathrm{mM} \mathrm{MgCl}_{2}$, $25 \mathrm{mM} \mathrm{NaCl}, 0.05 \%$ Triton X-100, $0.14 \mathrm{M}$ sucrose, $500 \mu \mathrm{g} / \mathrm{mL}$ heparin, $10 \mu \mathrm{g} / \mathrm{mL}$ aprotinin, and $10 \mu \mathrm{g} / \mathrm{mL}$ leupeptin). Polysomes were spun down at $55,000 \mathrm{rpm}$ for $20 \mathrm{~min}$ at $4^{\circ} \mathrm{C}$ in a Beckman TLA55 rotor, and the polysomal pellet was dissolved in buffer $\mathrm{H}$. Proteins were size-fractionated by SDS-PAGE, and phosphoproteins were identified by autoradiography.

\section{Polysomal fractionation and RNA analysis}

Polysomal fractionation and RNA analysis were performed as previously described (Tang et al. 2001). Preparation of liver cytoplasmic extracts was carried out as described (Aloni et al. 1992). The molecular probes used in blot hybridizations were previously described (Aloni et al. 1992).

\section{Rate of protein synthesis}

Subconfluent cultures of MEFs (passage 2) from $\mathrm{rpS6}^{\mathrm{P}+/+}$ and $\mathrm{rpS6}^{\mathrm{P}-/-}$ mice were grown in six-well plates. Cells were washed 
with PBS and then replenished with DMEM without methionine and cystein (Invitrogen), containing 10\% dialyzed fetal calf serum (Beit Haemek), 2 mM glutamine, 100 units/mL penicillin, and $0.1 \mathrm{mg} / \mathrm{mL}$ streptomycin. One hour later, cells were labeled with $10 \mu \mathrm{Ci}$ of EXPRE $^{35} S^{35} S$ (PerkinElmer) per well for 30 or $120 \mathrm{~min}$ and were then washed once with PBS containing methionine and cystein, $10 \mathrm{mM}$ each. Cells were lysed in $75 \mu \mathrm{L}$ of buffer $\mathrm{H}$ without aprotinin and leupeptin. Aliquots of $10 \mu \mathrm{L}$ were taken for precipitation in $10 \%$ trichloroacetic acid (TCA) containing methionine and cysteine, $10 \mathrm{mM}$ each. The precipitates were collected on filter (GF/C) and washed thrice with $5 \%$ TCA and once with ethanol. Filters were dried down and subjected to liquid scintillation counting with Opti-Fluor (Packard BioScience). Similar aliquots were used for protein determination (Lowry et al. 1951). The protein synthesis at each time point was calculated as TCA-precipitable counts per minute divided by micrograms of protein in the same sample.

\section{Measurement of ribosome half-transit time}

Cells $\left(3 \times 10^{7}\right)$ were suspended in $5 \mathrm{~mL}$ of labeling medium (Basal Medium-Eagle [Biological Industries] supplemented with $10 \%$ dialyzed bovine calf serum, $3.5 \mathrm{~g}$ glucose $/ \mathrm{L}$, and $2 \mathrm{mM}$ glutamine) for $20 \mathrm{~min}$ and then $10 \mu \mathrm{Ci} / \mathrm{mL}\left[4,5-{ }^{3} \mathrm{H}\right]$ leucine (Amersham Biosciences) was added. At the times indicated, cells were harvested, pelleted, and resuspended in $0.5 \mathrm{~mL}$ of RSB (10 mM NaCl, $10 \mathrm{mM}$ Tris- $\mathrm{HCl}$ at $\mathrm{pH} 7.4,15 \mathrm{mM} \mathrm{MgCl}_{2}$, and $100 \mu \mathrm{g} / \mathrm{mL}$ heparin). Cells were lysed by adding $70 \mu \mathrm{L}$ of Lysis buffer (10\% Triton X-100, 10\% deoxycholate) and subjecting them to $3 \mathrm{sec}$ on Vortex mix before and after $3 \mathrm{~min}$ of incubation on ice. Nuclei and mitochondria were pelleted by centrifugation for $10 \mathrm{~min}$ at maximum speed in a microfuge at $4^{\circ} \mathrm{C}$. Five-hundred microliters of the PMS were mixed with an equal volume of Polysomal buffer (25 mM Tris- $\mathrm{HCl}$ at $\mathrm{pH} 7.4,10 \mathrm{mM}$ $\mathrm{MgCl}_{2}, 25 \mathrm{mM} \mathrm{NaCl}, 0.05 \%$ Triton X-100, $0.14 \mathrm{M}$ sucrose, 500 $\mu \mathrm{g} / \mathrm{mL}$ heparin), and $450 \mu \mathrm{L}$ was removed to measure incorporation of $\left[{ }^{3} \mathrm{H}\right]$ leucine into total protein (nascent and completed). Polysomes were pelleted by centrifugation of the remaining supernatant at $55,000 \times \mathrm{g}$ for $20 \mathrm{~min}$ at $4^{\circ} \mathrm{C}$ in a Beckman TLA55 rotor. Four-hundred-fifty microliters of PRS were removed to measure the incorporation of $\left[{ }^{3} \mathrm{H}\right]$ leucine into completed protein. PMS and PRS samples were mixed with equal volumes of $20 \%$ TCA containing $10 \mathrm{mM}$ leucine, placed on ice for $20 \mathrm{~min}$, and then TCA precipitates were collected on a glass fiber filter (GF/C; Whatman). Filters were washed with ice-cold 10\% TCA, rinsed once with ethanol, and air-dried before being subjected to liquid scintillation counting.

\section{Immunofluorescence microscopy of pancreas sections}

Five-micrometer-thick sections from formalin-fixed, paraffinembedded pancreases were prepared. Slides were rehydrated, blocked with $1 \%$ BSA and $10 \%$ goat serum in phosphate buffered saline, $0.9 \% \mathrm{NaCl}$, and $0.3 \%$ Triton $\mathrm{X}-100$ (pH 7.4) (PBST), and incubated overnight at $4{ }^{\circ} \mathrm{C}$ with primary antibodies. After washing in PBST, slides were incubated for $1 \mathrm{~h}$ with fluorescent secondary antibodies, washed again, incubated briefly with 4',6diamidino-2-phenylindole (DAPI), and mounted. Digital images of islets and acinar tissue were obtained using an Olympus BX51 microscope (200× magnification), based on staining for insulin and amylase, respectively. The number of nuclei in a constant area $\left(2500 \mathrm{~mm}^{2}\right)$ was counted manually using ImagePro Plus software (Media Cybernetics). The primary antibodies used were guinea pig anti-insulin (DAKO) and rabbit anti-amylase (Sigma). The secondary antibodies used were CY2-anti- guinea pig (Jackson) and CY3-anti rabbit (Jackson). All antibodies were used at 1:200 dilution.

\section{Glucose and insulin tolerance tests and measurements of insulin levels}

A glucose tolerance test was performed on fasted $(17 \mathrm{~h})$ mice by injecting D-glucose intraperitoneally at a dose of $2.5 \mathrm{~g} / \mathrm{kg}$ of body weight. Whole venous blood was obtained from the tail at the indicated time points after the glucose load. Blood glucose levels were measured using a glucometer (Bayer). An insulin tolerance test was performed on fed mice by injecting human insulin (Humalog; Eli Lilly Corp.) intraperitoneally at a dose of $0.25 \mathrm{U} / \mathrm{kg}$ of body weight. To measure insulin concentration, blood was collected from the tail of 16 -h-fasted mice and centrifuged. Insulin levels were measured in $5 \mu \mathrm{L}$ of plasma using an enzyme-linked immunosorbent assay (ELISA) kit for mouse insulin (Mercodia $\mathrm{AB}$ ). Measurements of pancreatic insulin were carried out with pancreas homogenates using a rat insulin radioimmunoassay kit (Linco). A $t$-test was used for statistical analysis, and a $P$ value of 0.05 or less was considered significant.

\section{Measurement of total $\beta$-cell mass}

The whole pancreas was removed and weighed, fixed in zinc formalin for $4 \mathrm{~h}$, and embedded in paraffin. Five-micrometerthick sections were prepared through the whole block, and two consecutive slides every 100 microns were stained: one with guinea pig anti-insulin antibodies followed by HRP-conjugated anti-guinea pig antibody, and the other with hematoxylin and eosin. Stained slides were scanned at $4800 \times 4800$ dpi using a standard desktop scanner, and total tissue area, as well as total insulin-positive area, was calculated using Image-Pro Plus software. The fractional area occupied by $\beta$-cells was multiplied by pancreas weight to determine total $\beta$-cell mass. Control experiments using high-resolution images confirmed that this method takes into account all $\beta$-cells including most single cells.

\section{Acknowledgments}

We are grateful for the provision of mouse rpS6 genomic clones by Dr. A. Metspalu; large T-antigen expression vector by Dr. D. Ron; pancreatic insulin measurements by Dr. N. Kaiser; antirpS6 (phosphorylation-independent) antibody by Cell Signaling Technology; and numerous oligonucleotides by Integrated DNA Technologies (IDT). This work was supported by grants to O.M. from The Israel Science Foundation (grant no. 460/01-1), United States-Israel Binational Science Foundation (BSF 2000017), and The Otto Stieber Foundation.

\section{References}

Aloni, R., Peleg, D., and Meyuhas, O. 1992. Selective translational control and nonspecific posttranscriptional regulation of ribosomal protein gene expression during development and regeneration of rat liver. Mol. Cell. Biol. 12: 2203-2212.

Bernal-Mizrachi, E., Wen, W., Stahlhut, S., Welling, C.M., and Permutt, M.A. 2001. Islet $\beta$ cell expression of constitutively active $A k t 1 / \mathrm{PKB} \alpha$ induces striking hypertrophy, hyperplasia, and hyperinsulinemia. J. Clin. Invest. 108: 1631-1638.

Burgering, B.M.T. and Coffer, P.J. 1995. Protein kinase B (c-Akt) in phosphatidylinositol-3-OH kinase signal transduction. Nature 376: 599-602.

Chan, Y. and Wool, I. 1988. The primary structure of rat ribosomal protein S6. J. Biol. Chem. 263: 2891-2896. 
Chung, J., Kuo, C.J., Crabtree, G.R., and Blenis, J. 1992. Rapamycin-FKBP specifically blocks growth-dependent activation of and signaling by the $70 \mathrm{kD}$ S6 kinases. Cell 69: $1227-$ 1236.

Conlon, I.J., Dunn, G.A., Mudge, A.W., and Raff, M.C. 2001. Extracellular control of cell size. Nat. Cell Biol. 3: 918-921.

Conlon, I., Lloyd, A., and Raff, M. 2004. Coordination of cell growth and cell-cycle progression in proliferating mammalian cells. in Cell growth: Control of cell size (eds. M.N. Hall et al.|, pp. 85-99. Cold Spring Harbor Laboratory Press, Cold Spring Harbor, NY.

Dahri, S., Snoeck, A., Reusens-Billen, B., Remacle, C., and Hoet, J.J. 1991. Islet function in offspring of mothers on low-protein diet during gestation. Diabetes 40: 115-120.

de Groot, R., Ballou, L.M., and Sassone-Corsi, P. 1994. Positive regulation of the cAMP-responsive activator CREM by the p70 S6 kinase: An alternative route to mitogen-induced gene expression. Cell 79: 81-91.

Duncan, R. and McConkey, E.H. 1982. Preferential utilization of phosphorylated 40-S ribosomal subunits during initiation complex formation. Eur. J. Biochem. 123: 535-538.

Fan, H. and Penman, S. 1970. Regulation of protein synthesis in mammalian cells. II. Inhibition of protein synthesis at the level of initiation during mitosis. J. Mol. Biol. 50: 655-670.

Fingar, D.C. and Blenis, J. 2004. Target of rapamycin (TOR): An integrator of nutrient and growth factor signals and coordinator of cell growth and cell cycle progression. Oncogene 23: 3151-3171.

Fingar, D.C., Salama, S., Tsou, C., Harlow, E., and Blenis, J. 2002. Mammalian cell size is controlled by mTOR and its downstream targets S6K1 and 4EBP1/eIF4E. Genes \& Dev. 16: $1472-1487$.

Fumagalli, S. and Thomas, G. 2000. S6 phosphorylation and signal transduction. In Translational control of gene expression (eds. N. Sonenberg et al.), pp. 695-717. Cold Spring Harbor Laboratory Press, Cold Spring Harbor, NY.

Giordano, E., Cirulli, V., Bosco, D., Rouiller, D., Halban, P., and Meda, P. 1993. B-Cell size influences glucose-stimulated insulin secretion. Am. J. Physiol. 265: C358-C364.

Gressner, A.M. and Wool, I.G. 1974. The phosphorylation of liver ribosomal proteins in vivo. Evidence that only a single small subunit protein (S6) is phosphorylated. J. Biol. Chem. 249: 6917-6925.

Harada, H., Andersen, J., Mann, M., Terada, N., and Korsmeyer, S. 2001. p70S6 kinase signals cell survival as well as growth, inactivating the pro-apoptotic molecule BAD. Proc. Natl. Acad. Sci. 98: 9666-9670.

Harrington, L.S., Findlay, G.M., Gray, A., Tolkacheva, T., Wigfield, S., Rebholz, H., Barnett, J., Leslie, N.R., Cheng, S., Shepherd, P.R., et al. 2004. The TSC1-2 tumor suppressor controls insulin-PI3K signaling via regulation of IRS proteins. J. Cell Biol. 166: 213-223.

Hay, N. and Sonenberg, N. 2004. Upstream and downstream of mTOR. Genes \& Dev. 18: 1926-1945.

Hogan, B., Beddington, R., Costantini, F., and Lacy, E. 1994. Manipulating the mouse embryo. Cold Spring Harbor Laboratory Press, Cold Spring Harbor, NY.

Jefferies, H.B.J., Reinhard, C., Kozma, S.C., and Thomas, G. 1994. Rapamycin selectively represses translation of the 'polypyrimidine tract' mRNA family. Proc. Natl. Acad. Sci. 91: 4441-4445.

Johnson, S. and Warner, J. 1987. Phosphorylation of the Saccharomyces cerevisiae equivalent of ribosomal protein $\mathrm{S} 6$ has no detectable effect on growth. Mol. Cell. Biol. 7: 13381345 .
Krieg, J., Hofsteenge, J., and Thomas, G. 1988. Identification of the $40 \mathrm{~S}$ ribosomal protein $\mathrm{S} 6$ phosphorylation sites induced by cycloheximide. J. Biol. Chem. 263: 11473-11477.

Levy, S., Avni, D., Hariharan, N., Perry, R.P., and Meyuhas, O. 1991. Oligopyrimidine tract at the $5^{\prime}$ end of mammalian ribosomal protein mRNAs is required for their translational control. Proc. Natl. Acad. Sci. 88: 3319-3323.

Lowry, O.H., Rosebrough, N.J., Farr, A.L., and Randall, R.J. 1951. Protein measurement with the Folin-Phenol reagents. J. Biol. Chem. 193: 265-275.

Mazumder, B., Sampath, P., Seshadri, V., Maitra, R.K., DiCorleto, P.E., and Fox, P.L. 2003. Regulated release of L13a from the $60 \mathrm{~S}$ ribosomal subunit as a mechanism of transcriptspecific translational control. Cell 115: 187-198.

Meyuhas, O. 2000. Synthesis of the translational apparatus is regulated at the translational level. Eur. I. Biochem. 267: 6321-6330.

Montagne, J., Stewart, M.J., Stocker, H., Hafen, E., Kozma, S.C., and Thomas, G. 1999. Drosophila S6 kinase: A regulator of cell size. Science 285: 2126-2129.

Nygard, O. and Nika, H. 1982. Identification by RNA-protein cross-linking of ribosomal proteins located at the interface between the small and the large subunits of mammalian ribosomes. EMBO J. 1: 357-362.

Ohanna, M., Sobering, A.K., Lapointe, T., Lorenzo, L., Praud, C., Petroulakis, E., Sonenberg, N., Kelly, P.A., Sotiropoulos, A., and Pende, M. 2005. Atrophy of S6K1 ${ }^{-/-}$skeletal muscle cells reveals distinct mTOR effectors for cell cycle and size control. Nat. Cell Biol. 7: 286-294.

Oliver, M.H., Harrison, N.K., Bishop, J.E., Cole, P.J., and Laurent, G.J. 1989. A rapid and convenient assay for counting cells cultured in microwell plates: Application for assessment of growth factors. J. Cell Sci. 92: 513-518.

Pata, I. and Metspalu, A. 1996. Structural characterization of the mouse ribosomal protein S6-encoding gene. Genes Cells 175: 241-245.

Pende, M., Kozma, S.C., Jaquet, M., Oorschot, V., Burcelin, R., Le Marchand-Brustel, Y., Klumperman, J., Thorens, B., and Thomas, G. 2000. Hypoinsulinaemia, glucose intolerance and diminished $\beta$-cell size in S6K1-deficient mice. Nature 408: 994-997.

Pende, M., Um, S.H., Mieulet, V., Sticker, M., Goss, V.L., Mestan, J., Mueller, M., Fumagalli, S., Kozma, S.C., and Thomas, G. 2004. S6 $\mathrm{K}^{-1-} / \mathrm{S} 6 \mathrm{~K}^{-1-}$ mice exhibit perinatal lethality and rapamycin-sensitive $5^{\prime}$-terminal oligopyrimidine mRNA translation and reveal a mitogen-activated protein kinase-dependent S6 kinase pathway. Mol. Cell. Biol. 24: 3112-3124.

Proud, C.G. 2004. Ras, PI3-kinase and mTOR signaling in cardiac hypertrophy. Cardiovasc. Res. 63: 403-413.

Raught, B., Peiretti, F., Gingras, A.C., Livingstone, M., Shahbazian, D., Mayeur, G.L., Polakiewicz, R.D., Sonenberg, N., and Hershey, J.W. 2004. Phosphorylation of eucaryotic translation initiation factor 4B Ser422 is modulated by S6 kinases. EMBO I. 23: 1761-1769.

Ravelli, A.C., van der Meulen, J.H., Michels, R.P., Osmond, C., Barker, D.J., Hales, C.N., and Bleker, O.P. 1998. Glucose tolerance in adults after prenatal exposure to famine. Lancet 351: $173-177$.

Richardson, C.J., Broenstrup, M., Fingar, D.C., Julich, K., Ballif, B.A., Gygi, S., and Blenis, J. 2004. SKAR is a specific target of S6 kinase 1 in cell growth control. Curr. Biol. 14: 1540-1549. Schumacher, M., Staege, M.S., Pajic, A., Polack, A., Weidle, U.H., Bornkamm, G.W., Eick, D., and Kohlhuber, F. 1999. Control of cell growth by c-Myc in the absence of cell divi- 
sion. Curr. Biol. 9: 1255-1258.

Shima, H., Pende, M., Chen, Y., Fumagalli, S., Thomas, G., and Kozma, S.C. 1998. Disruption of the $\mathrm{p} 70^{\mathrm{s} 6 \mathrm{k}} / \mathrm{p} 85^{\mathrm{s} 6 \mathrm{k}}$ gene reveals a small mouse phenotype and a new functional S6 kinase. EMBO J. 17: 6649-6659.

Stolovich, M., Tang, H., Hornstein, E., Levy, G., Cohen, R., Bae, S.S., Birnbaum, M.J., and Meyuhas, O. 2002. Transduction of growth or mitogenic signals into translational activation of TOP mRNAs is fully reliant on the PI3-kinase-mediated pathway, but requires neither S6K1 nor rpS6 phosphorylation. Mol. Cell. Biol. 22: 8101-8113.

Tang, H., Hornstein, E., Stolovich, M., Levy, G., Livingstone, M., Templeton, D.J., Avruch, J., and Meyuhas, O. 2001. Amino acid-induced translation of TOP mRNAs is fully dependent on PI3-kinase-mediated signaling, is partially inhibited by rapamycin, and is independent of S6K1 and rpS6 phosphorylation. Mol. Cell. Biol. 21: 8671-8683.

Thomas, G., Martin-Pérez, J., Siegmann, M., and Otto, A.M. 1982. The effect of serum, EGF, $\mathrm{PGF}_{2 \alpha}$, and insulin on S6 phosphorylation and the initiation of protein and DNA synthesis. Cell 30: 235-242.

Tuttle, R.L., Gill, N.S., Pugh, W., Lee, J.P., Koeberlein, B., Furth, E.E., Polonsky, K.S., Naji, A., and Birnbaum, M.J. 2001. Regulation of pancreatic $\beta$-cell growth and survival by the serine/threonine protein kinase $\operatorname{Akt} 1 / \mathrm{PKB} \alpha$. Nat. Med. 7: 1133-1137.

Um, S.H., Frigerio, F., Watanabe, M., Picard, F., Joaquin, M., Sticker, M., Fumagalli, S., Allegrini, P.R., Kozma, S.C., Auwerx, J., et al. 2004. Absence of S6K1 protects against ageand diet-induced obesity while enhancing insulin sensitivity. Nature 431: 200-205.

Volarevic, S., Stewart, M.J., Ledermann, B., Zilberman, F., Terracciano, L., Montini, E., Grompe, M., Kozma, S.C., and Thomas, G. 2000. Proliferation, but not growth, blocked by conditional deletion of $40 \mathrm{~S}$ ribosomal protein S6. Science 288: 2045-2047.

Wang, X., Li, W., Williams, M., Terada, N., Alessi, D.R., and Proud, C.G. 2001. Regulation of elongation factor 2 kinase by $\mathrm{p} 90^{R S K 1}$ and $\mathrm{p} 70$ S6 kinase. EMBO J. 20: 4370-4379.

Wilson, K.F., Wu, W.J., and Cerione, R.A. 2000. Cde42 stimulates RNA splicing via the S6 kinase and a novel S6 kinase target, the nuclear cap-binding complex. J. Biol. Chem. 275: $37307-37310$. 


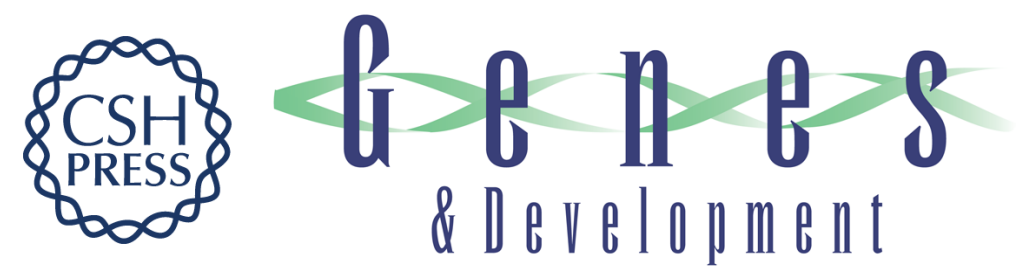

\section{Ribosomal protein S6 phosphorylation is a determinant of cell size and glucose homeostasis}

Igor Ruvinsky, Nitzan Sharon, Tal Lerer, et al.

Genes Dev. 2005, 19:

Access the most recent version at doi:10.1101/gad.351605

References

This article cites 43 articles, 22 of which can be accessed free at:

http://genesdev.cshlp.org/content/19/18/2199.full.html\#ref-list-1

\section{License}

Email Alerting

Receive free email alerts when new articles cite this article - sign up in the box at the top

Service right corner of the article or click here.

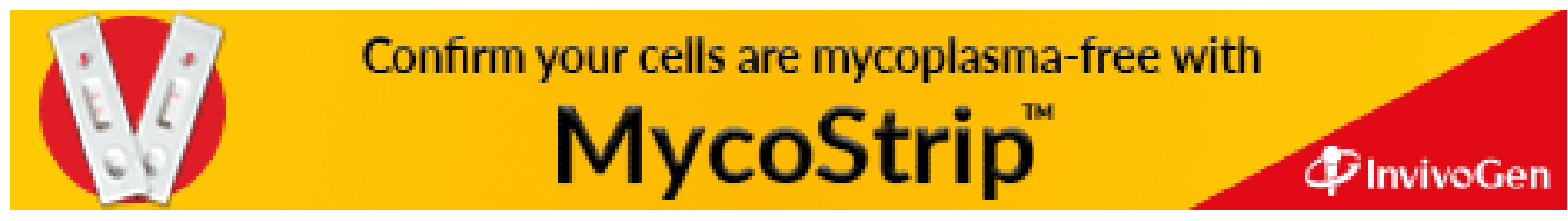

